\title{
Corrosion Behavior of Ti-Based Metallic Glasses
}

\author{
Fengxiang Qin, Xinmin Wang, Asahi Kawashima, Shengli Zhu, \\ Hisamichi Kimura and Akihisa Inoue
}

\author{
Institute for Materials Research, Tohoku University, Sendai 980-8577, Japan
}

\begin{abstract}
The corrosion behavior of the $\mathrm{Ti}_{47.5} \mathrm{Cu}_{42.5} \mathrm{Ni}_{7.5} \mathrm{Zr}_{2.5}$ metallic glass as well as its modified glasses by the addition of 5 at $\% \mathrm{Co}, \mathrm{Nb}$ or $\mathrm{Ta}$ was investigated by electrochemical measurements. Potentiodynamic polarization was carried out in $0.14 \mathrm{kmol} / \mathrm{m}^{3} \mathrm{NaCl}$ solution and $0.2 \mathrm{kmol} / \mathrm{m}^{3}$ phosphate buffer solution with $0.14 \mathrm{kmol} / \mathrm{m}^{3} \mathrm{Cl}^{-}$ion. All the metallic glasses examined were spontaneously passivated with significantly low passive current density in sodium chloride solution and phosphate buffer solution. The additional elements improve the corrosion resistance and the effect of $\mathrm{Nb}$ or Ta is particular. The results of XPS revealed that the passive films were rich in titanium and deficient in copper and nickel. The higher corrosion resistance for the modified glasses is attributed to stable and protective passive films enriched with titanium cation contained certain amount of additional elements. In phosphate buffer solution, the pitting potentials for all glasses are higher than those in $\mathrm{NaCl}$ solution possibly due to inhibiting ability of phosphate ion absorbing on the glassy surface. [doi:10.2320/matertrans.47.1934]
\end{abstract}

(Received April 25, 2006; Accepted June 12, 2006; Published August 15, 2006)

Keywords: Titanium-based metallic glass, passivation, X-ray photoelectron spectroscopy

\section{Introduction}

The metallic glasses are expected to have high corrosion resistance due to their chemical and structural homogeneity. They do not contain crystalline defects, such as grain boundaries or dislocations acting as nucleation sites for corrosion. Thus, the glassy state provides the formation of a uniform passive film without weak points with respect to corrosion. Ti-based metallic glasses have high strength, low Young's modulus and excellent biocompatibility with a high potential to be applied as aerospace materials and biomaterials in the future. So far Ti-based metallic glasses are mainly developed on $\mathrm{Ti}-\mathrm{Cu}-\mathrm{Ni}^{1)}$ system. Based on the Inoue's three empirical rules, ${ }^{2,3)}$ i.e., 1) multicomponent consisting of more than three elements, 2) significant atomic size mismatches above $12 \%$ among the main three elements, and 3 ) negative heats of mixing among the main elements, a series of Tibased metallic glasses have been developed by adding some elements, for example, $\mathrm{Ti}-\mathrm{Cu}-\mathrm{Ni}-\mathrm{Co},{ }^{4)} \mathrm{Ti}-\mathrm{Cu}-\mathrm{Ni}-\mathrm{Zr},{ }^{5} \mathrm{Ti}-\mathrm{Cu}-$ $\mathrm{Ni}-\mathrm{Zr}-\mathrm{Sn},{ }^{6)}$ Ti-Cu-Ni-Sn-B-Si, ${ }^{7)}$ Ti-Cu-Ni-Sn-Be, ${ }^{8)}$ Ti-Cu$\mathrm{Ni}-\mathrm{Zr}-\mathrm{Be}^{9)}$ and $\mathrm{Ti}-\mathrm{Cu}-\mathrm{Ni}-\mathrm{Zr}-\mathrm{Hf}-\mathrm{Si}^{10)}$ and so on, for which the critical diameters for glass formation range from 1 to $8 \mathrm{~mm}$ by copper mold casting. The maximum size of $8 \mathrm{~mm}$ for Tibased bulk metallic glass has been fabricated in $\mathrm{Ti}-\mathrm{Cu}-\mathrm{Ni}-\mathrm{Zr}$ Be system. So far many researchers have studied glassforming ability, thermal stability and mechanical properties of all those Ti-based metallic glasses. But the data on the corrosion behavior of Ti-based metallic glasses have been comparatively rare. The application of Ti-based metallic glasses needs an acceptable life time in different environments. So it is of scientific and technological importance to research on corrosion behavior of Ti-based metallic glasses. In this paper, the corrosion resistance of $\mathrm{Ti}_{47.5} \mathrm{Cu}_{42.5} \mathrm{Ni}_{7.5^{-}}$ $\mathrm{Zr}_{2.5}$ metallic glass and its modified alloys with $5 \mathrm{at} \% \mathrm{Co}, \mathrm{Nb}$ or Ta substituted for a part of $\mathrm{Cu}$ was investigated in 0.14 $\mathrm{kmol} / \mathrm{m}^{3} \mathrm{NaCl}$ solution and $0.2 \mathrm{kmol} / \mathrm{m}^{3}$ phosphate buffer solution.

\section{Experimental Procedure}

The alloys with nominal compositions of $\mathrm{Ti}_{47.5} \mathrm{Cu}_{37.5^{-}}$ $\mathrm{Ni}_{7.5} \mathrm{Zr}_{2.5} \mathrm{M}_{5}(\mathrm{M}=\mathrm{Cu}, \mathrm{Co}, \mathrm{Nb}$ or $\mathrm{Ta})$ were prepared by arc melting the mixture of pure metals ( $>99.9$ mass $\%$ ) in an argon atmosphere. The metallic glassy ribbons of $1 \mathrm{~mm}$ in width and $35 \mu \mathrm{m}$ in thickness were produced by melt spinning. The structure of as-spun samples was examined by $\mathrm{X}$-ray diffraction (XRD) with $\mathrm{Cu} \mathrm{K} \alpha$ radiation. Thermal stability was characterized by differential scanning calorimetry (DSC) under argon atmosphere with a heating rate of $0.67 \mathrm{~K} / \mathrm{s}$.

The corrosion behavior of the metallic glasses was evaluated by electrochemical measurements. Electrolytes used was $0.14 \mathrm{kmol} / \mathrm{m}^{3} \mathrm{NaCl}$ solution ( $\left.\mathrm{pH} 5.7\right)$ and 0.2 $\mathrm{kmol} / \mathrm{m}^{3}$ phosphate buffer solution $\left(0.2 \mathrm{kmol} / \mathrm{m}^{3} \quad \mathrm{Na}_{2}-\right.$ $\left.\mathrm{HPO}_{4}+0.2 \mathrm{kmol} / \mathrm{m}^{3} \mathrm{NaH}_{2} \mathrm{PO}_{4}\right)$ with $0.14 \mathrm{kmol} / \mathrm{m}^{3} \mathrm{Cl}^{-}$ion ( $\mathrm{pH}$ 5.5) at room temperature open to air, which was prepared from reagent grade chemical and deionized water. Electrochemical measurements were conducted in a three-electrode cell using a platinum counter electrode and a saturated calomel reference electrode (SCE). Potentiodynamic polarization curves were measured with a potential sweep rate of $0.83 \times 10^{-3} \mathrm{~V} / \mathrm{s}$ in the solutions after immersing the specimens for about $600 \mathrm{~s}$, when the open-circuit potentials became almost steady. XPS spectra for the surface of the metallic glasses after potentiostatic polarization were measured by means of a SSI SSX-100 photoelectron spectrometer with monochromatized $\mathrm{Al} \mathrm{K} \alpha$ excitation $(h v=1486.6 \mathrm{eV})$.

\section{Results and Discussion}

\subsection{Thermal stability}

The structure of the as-spun Ti-based metallic glasses was confirmed to be glassy by XRD. The corresponding DSC curves of the samples under a constant heating rate of 0.67 $\mathrm{K} / \mathrm{s}$ are shown in Fig. 1 . The glass transition temperature $\left(T_{\mathrm{g}}\right)$ and onset temperature of crystallization $\left(T_{x}\right)$ appear in all alloys demonstrating their glassy nature. Moreover, a 


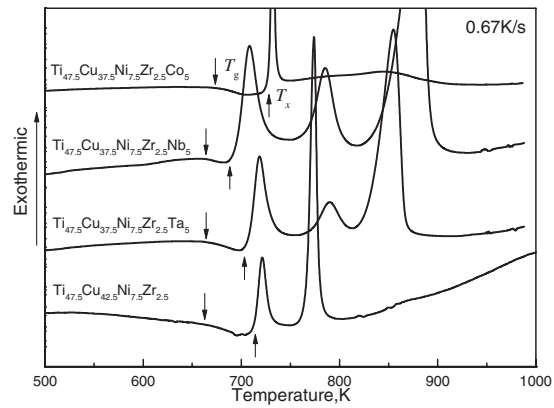

Fig. 1 DSC curves of the melt-spun $\mathrm{Ti}_{47.5}$ $\mathrm{Cu}_{37.5} \mathrm{Ni}_{7.5} \mathrm{Zr}_{2.5} \mathrm{M}_{5}(\mathrm{M}=\mathrm{Cu}, \mathrm{Co}, \mathrm{Nb}$ or $\mathrm{Ta})$ metallic glasses.

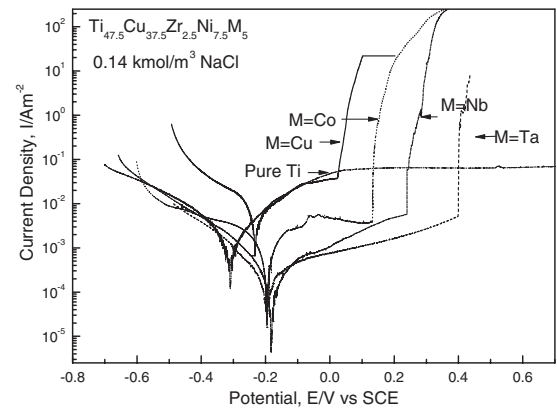

Fig. 2 Anodic and cathodic polarization curves of the melt-spun $\mathrm{Ti}_{47.5} \mathrm{Cu}_{37.5} \mathrm{Ni}_{7.5} \mathrm{Zr}_{2.5} \mathrm{M}_{5}(\mathrm{M}=$ $\mathrm{Cu}, \mathrm{Co}, \mathrm{Nb}$ or $\mathrm{Ta}$ ) metallic glasses in 0.14 $\mathrm{kmol} / \mathrm{m}^{3} \mathrm{NaCl}$ solution.

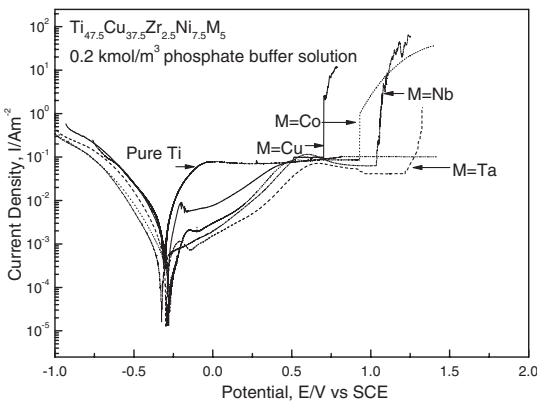

Fig. 3 Anodic and cathodic polarization curves of the melt-spun $\mathrm{Ti}_{47.5} \mathrm{Cu}_{37.5} \mathrm{Ni}_{7.5} \mathrm{Zr}_{2.5} \mathrm{M}_{5}(\mathrm{M}=$ $\mathrm{Cu}, \mathrm{Co}, \mathrm{Nb}$ or $\mathrm{Ta}$ ) metallic glasses in 0.2 $\mathrm{kmol} / \mathrm{m}^{3}$ phosphate buffer solution. large supercooled liquid region $\Delta T_{x}$ before crystallization can be observed, meaning that these alloys exhibit a high thermal stability against crystallization. It can be seen that $T_{\mathrm{g}}$ slightly increases from $662 \mathrm{~K}$ for the $\mathrm{Ti}_{47.5} \mathrm{Cu}_{42.5} \mathrm{Ni}_{7.5} \mathrm{Zr}_{2.5}$ (denoted as base glass) to 664,665 and $673 \mathrm{~K}$ for the $\mathrm{Ta}-, \mathrm{Nb}-$ and Co-containing metallic glasses, respectively. $T_{x}$ increase from $714 \mathrm{~K}$ for the base glass to $731 \mathrm{~K}$ for the Co-containing glass, while it decreases to 708 and $692 \mathrm{~K}$ for the Ta- and Nbcontaining glasses. So it can be deduced that $\Delta T_{x}$ is $52,44,30$ and $58 \mathrm{~K}$ for the base alloy, $\mathrm{Ta}-, \mathrm{Nb}$ - and Co-containing glasses, respectively. And the crystalline peaks combine to a single peak with the addition of Co.

It is obvious that the addition of $\mathrm{Nb}$ or $\mathrm{Ta}$ for $\mathrm{Ti}-\mathrm{Cu}-\mathrm{Ni}-\mathrm{Zr}$ metallic glass results in the decrease of thermal stability, while the addition of Co increases the thermal stability. It has been reported that the addition of $\mathrm{Nb}$, Ta or Mo decreases $\Delta T_{x}$ in $\mathrm{Cu}-\mathrm{Zr}-\mathrm{Ti}$ glassy system, ${ }^{11)}$ and the same effect is recognized with the addition of $\mathrm{Nb}$ in $\mathrm{Cu}-\mathrm{Hf}-\mathrm{Ti}$ glassy system $^{12)}$ due to the departure from the three empirical rules. In the case of Co addition, $T_{\mathrm{g}}, T_{x}$ and $\Delta T_{x}$ have all been increased. The predicted heat of mixing ${ }^{13)}$ for glassy alloy is $-28 \mathrm{~kJ} / \mathrm{mol}$ for Ti-Co, $1 \mathrm{~kJ} / \mathrm{mol}$ for Ti-Ta and $2 \mathrm{~kJ} / \mathrm{mol}$ for $\mathrm{Ti}-\mathrm{Nb}$ pairs. Furthermore, the addition of Co causes a more large change in atomic size. The atomic radius is 2.00, 2.08, 2.07 and $1.67 \mathrm{~nm}$ for $\mathrm{Ti}, \mathrm{Nb}$, Ta and Co, respectively. These changes by the addition of Co increase the degree to satisfy the three empirical rules for the thermal stability of the supercooled liquid. The atomic size effect and the large negative heat of mixing are believed to be helpful for stabilizing a glassy structure. ${ }^{14)}$ It may be the reason why the thermal stability of the $\mathrm{Ti}_{47.5} \mathrm{Cu}_{42.5} \mathrm{Ni}_{7.5} \mathrm{Zr}_{2.5}$ metallic glass has been improved by adding 5 at $\%$ Co element.

\subsection{Potentiodynamic polarization curves}

The polarization curves of the $\mathrm{Ti}_{47.5} \mathrm{Cu}_{42.5} \mathrm{Ni}_{7.5} \mathrm{Zr}_{2.5}$ metallic glass and its modified glasses comparing with commercial pure $\mathrm{Ti}$ in $0.14 \mathrm{kmol} / \mathrm{m}^{3} \mathrm{NaCl}$ solution are shown in Fig. 2. All Ti-based metallic glasses are spontaneously passivated in anodic polarization process. As compared with the base glass, the modified glasses containing $\mathrm{Co}, \mathrm{Nb}$ or $\mathrm{Ta}$ exhibit much lower passive current density and wider passive regions, indicating that the addition of $\mathrm{Co}, \mathrm{Nb}$ or $\mathrm{Ta}$ can promote the formation of more protective film on the surface of the Ti-based metallic glasses. The passive current densities of the $\mathrm{Co}-, \mathrm{Nb}-$ or Ta-containing glass are located between $10^{-2}$ and $10^{-3} \mathrm{~A} / \mathrm{m}^{2}$, much lower than that of pure $\mathrm{Ti}$ and more than one order of magnitude lower than that of the base glass. And substitution of $\mathrm{Cu}$ by the additional elements also results in the decrease of corrosion current density. The corrosion current densities were obtained from the polarization curves by extrapolation of the cathodic branch of the polarization curves to the corrosion potential. The corrosion current densities are $5.1 \times 10^{-3}, 1.5 \times 10^{-3}, 1.8 \times 10^{-4}$ and $1.7 \times 10^{-4} \mathrm{~A} / \mathrm{m}^{2}$ for the base glass, $\mathrm{Co}-, \mathrm{Nb}-$ and Ta-containing glasses, respectively. However, at potentials above $0 \mathrm{~V}$ the sharp increase in current density suggests that the passive film is seriously destroyed, that is pitting corrosion occurs. Furthermore the pitting potential for Ta-, $\mathrm{Nb}$ - or Co-containing glass is about 400,200 and $150 \mathrm{mV}$, respectively, higher than that of the base glass. Recently, it has been reported that, ${ }^{11,12)}$ in $\mathrm{Cu}-\mathrm{Zr}-\mathrm{Ti}$ and $\mathrm{Cu}-\mathrm{Hf}-\mathrm{Ti}$ bulk metallic glasses, addition of $\mathrm{Nb}$ or $\mathrm{Ta}$ is effective for corrosion resistance in different solutions because $\mathrm{Nb}$ or $\mathrm{Ta}$ can improve the stability of passive film.

Figure 3 presents the anodic and cathodic polarization curves for Ti-based metallic glasses and pure Ti in $0.2 \mathrm{kmol} /$ $\mathrm{m}^{3}$ phosphate buffer solution with $0.14 \mathrm{kmol} / \mathrm{m}^{3} \mathrm{Cl}^{-}$. The current density of all Ti-based metallic glasses increases with the potential till $500 \mathrm{mV}$ by anodic polarization. Then the current density maintains constant value between $10^{-2}$ and $10^{-1} \mathrm{~A} / \mathrm{m}^{2}$ till the pitting potential. Different from the results in $\mathrm{NaCl}$, higher pitting potential can be observed in phosphate buffer solution. The pitting potentials for all metallic glasses in phosphate buffer solution are much higher than those in sodium chloride solution. Hiromoto ${ }^{15)}$ also reported that the adsorbed phosphate ion inhibited pitting corrosion in $\mathrm{Zr}-\mathrm{Al}-\mathrm{Ni}-\mathrm{Cu}$ glassy ribbon in the phosphate buffer solution.

\subsection{Composition of surface film}

For a better understanding of the corrosion behavior, XPS was performed for the glassy samples after potentiodynamic polarization at $-50 \mathrm{mV}$ in $\mathrm{NaCl}$ and at $100 \mathrm{mV}$ in the phosphate buffer solution.

The XPS spectra from the $\mathrm{Ti}_{47.5} \mathrm{Cu}_{37.5} \mathrm{Ni}_{7.5} \mathrm{Zr}_{2.5} \mathrm{M}_{5}(\mathrm{M}=$ $\mathrm{Cu}, \mathrm{Co}, \mathrm{Nb}$ or $\mathrm{Ta}$ ) after polarization treatment in $\mathrm{NaCl}$ over a wide binding energy region exhibited peaks of carbon, oxygen, titanium, zirconium, copper and the additional elements. The $\mathrm{C} 1 \mathrm{~s}$ peaks were those from carbon in alloys 

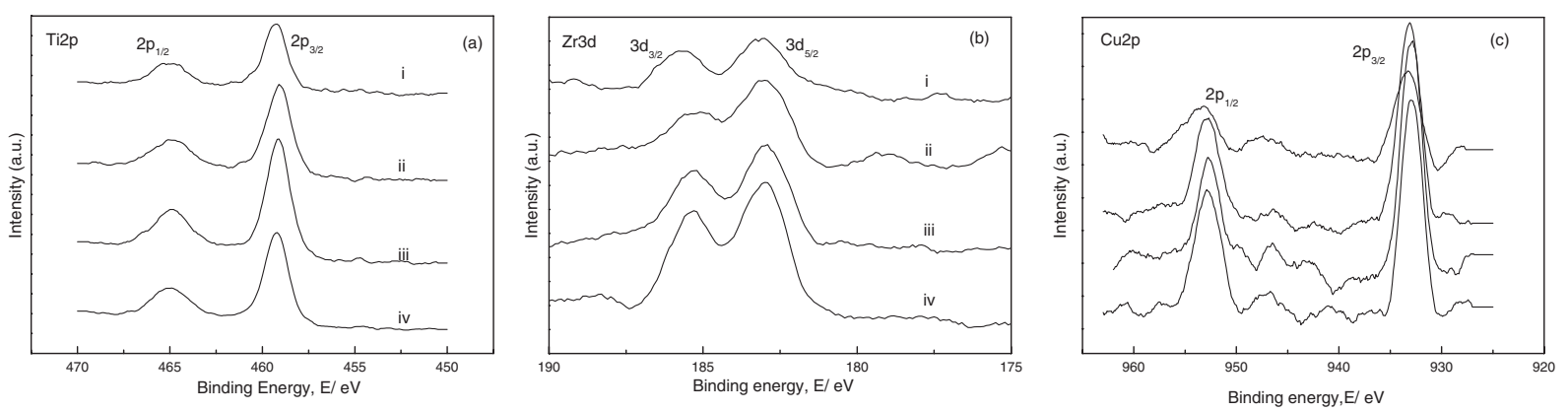

Fig. 4 XPS peaks of the $\mathrm{Ti}_{47.5} \mathrm{Cu}_{37.5} \mathrm{Ni}_{7.5} \mathrm{Zr}_{2.5} \mathrm{M}_{5}(\mathrm{M}=\mathrm{Cu}(\mathrm{i}), \mathrm{Co}$ (ii), $\mathrm{Nb}$ (iii) or $\mathrm{Ta}$ (iv))metallic glasses after polarization at potential of $-50 \mathrm{mV}$ in $0.14 \mathrm{kmol} / \mathrm{m}^{3} \mathrm{NaCl}$ for $3600 \mathrm{~s}$. (a) $\mathrm{Ti} 2 \mathrm{p}$; (b) $\mathrm{Zr} \mathrm{3d}$; (c) $\mathrm{Cu} 2 \mathrm{p}$.

and so-called contaminant carbon on the top of surface of specimens. All the oxygen came from surface oxide. The $\mathrm{O} 1 \mathrm{~s}$ spectra measured were composed of two peaks at 530.1-530.8 and 529.9-533.2 eV, which were assigned to $\mathrm{OM}$ oxygen and $\mathrm{OH}$ oxygen, respectively. The OM oxygen denotes oxygen with a metal-oxygen bond, such as $\mathrm{O}^{2-}$ ions. The XPS of Ti 2p, $\mathrm{Zr} 3 \mathrm{~d}$ and $\mathrm{Cu} 2 \mathrm{p}$ electrons obtained from the alloy surface after polarized at $-50 \mathrm{mV}$ in $\mathrm{NaCl}$ are presented in Fig. 4. The Ti $2 p$ spectra are composed of two main peaks, which are identified as $\mathrm{Ti} 2 \mathrm{p}_{1 / 2}$ and $\mathrm{Ti} 2 \mathrm{p}_{3 / 2}$, originating from $\mathrm{TiO}_{2}$ (Fig. 4(a)). The $\mathrm{Zr} 3 \mathrm{~d}$ spectrum consists of two peaks by multiplet splitting, $3 \mathrm{~d}_{5 / 2}$ and $3 \mathrm{~d}_{3 / 2}$. The peaks at $182.7-182.9 \mathrm{eV}$ and $185.0-185.3 \mathrm{eV}$ were assigned as $\mathrm{Zr} 3 \mathrm{~d}_{5 / 2}$ and $\mathrm{Zr} 3 \mathrm{~d}_{3 / 2}$ electrons originating from the $\mathrm{Zr}^{4+}$, as shown in Fig. 4(b). Peaks at $932.8-933.3 \mathrm{eV}$ and 952.2-953.0 eV are observed on the $\mathrm{Cu} 2 \mathrm{p}$ spectrum region for all metallic alloys (Fig. 4(c)), with a specific peak between the $2 p_{3 / 2}$ and $2 p_{1 / 2}$ spectra, characteristic of the peak for $\mathrm{CuO}$. In the spectra of $\mathrm{Nb} 3 \mathrm{~d}$ (not shown), a doublet of oxidized state was observed at about 208.0 and $210.6 \mathrm{eV}$. Ta $4 \mathrm{f}_{7 / 2}$ and $\mathrm{Ta} 4 \mathrm{f}_{5 / 2}$ electron peaks (not shown) corresponding to the oxidated state of $\mathrm{Ta}^{5+}$ were located at about 27.0 and $28.5 \mathrm{eV}$, respectively. In addition, no metallic peaks corresponding to $\mathrm{Ti}, \mathrm{Cu}, \mathrm{Zr}, \mathrm{Nb}$ and $\mathrm{Ta}$ were detected as metallic peaks after polarization, which indicates that all the elements have mostly been oxidized in the sample surfaces. It should be pointed out that no peak corresponding to $\mathrm{Ni}$ for all the metallic glasses and Co for the Co-containing glass is detected not only for polarization samples but also for native samples. These results suggest that films grown anodically on the Ti-based metallic glasses consist of mixed oxides containing $\mathrm{TiO}_{2}, \mathrm{CuO}$ and $\mathrm{ZrO}_{2}$ as well as $\mathrm{Nb}_{2} \mathrm{O}_{5}$ or $\mathrm{Ta}_{2} \mathrm{O}_{5}$. Kawashima et al. have found that ${ }^{16)} \mathrm{Ni}$ is largely deficient in air-formed film, while it is slightly enrichment in the underlying alloy surface because $\mathrm{Ni}$ is not oxidized by air exposure in $\mathrm{Ni}-\mathrm{Nb}-\mathrm{Ta}-\mathrm{P}$ amorphous alloy system. In our study, the main constitute $\mathrm{Ti}$ is easily oxidized in air, at the same time $\mathrm{Ni}$ is not oxidized by air exposure. ${ }^{17}$ So Ni can not be detected after the diffusion of a large amount of Ti to the outer surface. Considering that Co has similar chemical properties as $\mathrm{Ni}$, it is deduced that Co may play the same role in this alloy system.

Similar results were obtained from the surface of the Tibased metallic glasses polarized at $100 \mathrm{mV}$ in phosphate buffer solution. In addition to the alloy composition elements, P 2 p spectra were also detected in the wide spectra
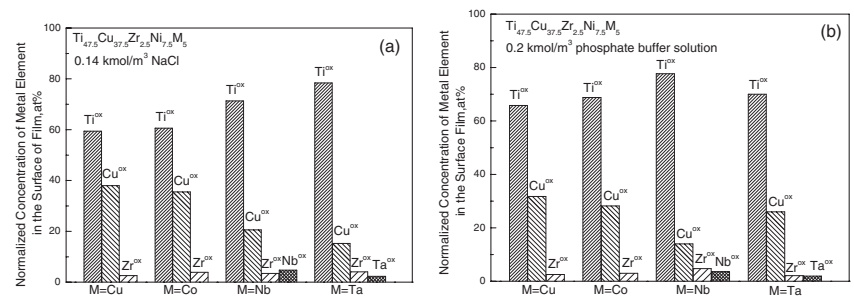

Fig. 5 Fractions of element $\mathrm{M}(\mathrm{Ti}, \mathrm{Zr}, \mathrm{Cu}, \mathrm{Nb}$ or $\mathrm{Ta})$ in the surface film of the $\mathrm{Ti}_{47.5} \mathrm{Cu}_{37.5} \mathrm{Ni}_{7.5} \mathrm{Zr}_{2.5} \mathrm{M}_{5}(\mathrm{M}=\mathrm{Cu}, \mathrm{Co}, \mathrm{Nb}$ or Ta $)$ metallic glasses after polarization for $3600 \mathrm{~s}$ in (a) $0.14 \mathrm{kmol} / \mathrm{m}^{3} \mathrm{NaCl}$ solution and (b) 0.2 $\mathrm{kmol} / \mathrm{m}^{3}$ phosphate buffer solution.

for the surface of the metallic glasses after polarization treatment in phosphate buffer solution. P $2 \mathrm{p}$ electron peak was obtained at $134.2-134.6 \mathrm{eV}$, which was assigned to the P $2 p$ electron from $\mathrm{HPO}_{4}{ }^{-18)}$ which originated from the solution.

The atomic concentrations of elements in the surface film were calculated from the integrated intensity of the spectra. Figure 5 shows the concentration of the elements of $\mathrm{Ti}, \mathrm{Cu}$ and $\mathrm{Zr}$ as well as $\mathrm{Nb}$ or $\mathrm{Ta}$ in the surface films formed on the alloys. Comparing the changes in the cationic fractions of the surface film for the samples after polarization in $\mathrm{NaCl}$ solution, it is seen that the Ti concentration of the $\mathrm{Nb}$ - or Tacontaining glass is increased, and $\mathrm{Zr}$ also increases slightly, while the $\mathrm{Cu}$ concentration in surface films deceases seriously with the addition of $\mathrm{Nb}$ or $\mathrm{Ta}$. But the change for the Co-containing glass is not remarkable. Asami et al. ${ }^{11)}$ also reported that $\mathrm{Zr}$ was enriched with addition of $\mathrm{Nb}$ in $\mathrm{Cu}-\mathrm{Zr}-\mathrm{Ti}$ bulk metallic glass, and the high corrosion resistance is attributed to the formation of $\mathrm{Zr}$-rich surface film in $\mathrm{Cl}^{-}$ion containing solutions. It is well known that titanium oxide is very stable in many solutions and $\mathrm{Ta}$ or $\mathrm{Nb}$ is generally effective in improving corrosion resistance. As indicated by the results of polarization curves in Fig. 2, much lower passive current densities have been obtained with the addition of $\mathrm{Nb}$ or $\mathrm{Ta}$. The enrichment of $\mathrm{Ti}$, and the mixing of certain amount of $\mathrm{Nb}$ or Ta oxides in the passive film are responsible to the higher corrosion resistance. But the role of Co is not so clear in this study. Further study should be carried out. The concentrations of $\mathrm{Ti}$ in the oxide film formed in the phosphate buffer solution are also considerably higher than that of the normal alloy due to the preferential oxidation.The atomic fraction of $\mathrm{Cu}$ is much lower than that of the normal alloy, suggesting that the $\mathrm{Cu}$ elements are 
preferentially dissolved from the glass surface during the process of polarization in the solution containing $\mathrm{Cl}^{-}$ion. Although the basic chemical composition is often a dominant factor in controlling the relative corrosion resistance in all materials, the tendency of a metal to passivate depends on all of composition, structure and solution chemistry. In different cases, different factors or combinations of several factors may control corrosion resistance of metal materials. In this study, both the solutions contain $0.14 \mathrm{kmol} / \mathrm{m}^{3} \mathrm{Cl}^{-}$ion. In $0.14 \mathrm{kmol} / \mathrm{m}^{3} \mathrm{NaCl}$ solution, the addition of $\mathrm{Co}, \mathrm{Nb}$ or $\mathrm{Ta}$ enhances the formation of more protective film in the surface. But pitting corrosion still occurs at the potential higher than $0 \mathrm{~V}$ due to the existence of aggressive $\mathrm{Cl}^{-}$ion. On the other hand, in phosphate buffer solution, although the same amount of $\mathrm{Cl}^{-}$ion exists as that in $\mathrm{NaCl}$ solution, the phosphate ion seems to inhibit the pitting corrosion, i.e., the phosphate ion plays an important role in inhibiting corrosion. Consequently the Ti-based metallic glasses exhibited high pitting resistance in this solution.

\section{Conclusions}

The corrosion behaviour of the melt-spun $\mathrm{Ti}_{47.5} \mathrm{Cu}_{37.5^{-}}$ $\mathrm{Ni}_{7.5} \mathrm{Zr}_{2.5} \mathrm{M}_{5}(\mathrm{M}=\mathrm{Cu}, \mathrm{Co}, \mathrm{Nb}$ or $\mathrm{Ta})$ glasses in $0.14 \mathrm{kmol} /$ $\mathrm{m}^{3} \mathrm{NaCl}$ solution and $0.2 \mathrm{kmol} / \mathrm{m}^{3}$ phosphate buffer solution has been investigated by electrochemical method and XPS. By addition of $5 \mathrm{at} \% \mathrm{Co}, \mathrm{Nb}$ or Ta, corrosion resistance is improved in $\mathrm{NaCl}$. The passive current density of the modified glasses is located between $10^{-2}$ and $10^{-3} \mathrm{~A} / \mathrm{m}^{2}$, one order of magnitude lower than that of the $\mathrm{Ti}_{47.5} \mathrm{Cu}_{42.5^{-}}$ $\mathrm{Ni}_{7.5} \mathrm{Zr}_{2.5}$ alloy, meaning that stable and more protective film formed during anodic polarization. The higher corrosion resistance is attributed to the enrichment of $\mathrm{Ti}$ and certain amounts of additional elements existing in the surface film for the modified glasses. The pitting potentials in phosphate buffer solution are higher than those in $\mathrm{NaCl}$ possibly due to inhibition of phosphate ion absorbing on the glasses surface.

\section{Acknowledgments}

We would like to acknowledge Professor K. Asami for the constructive suggestions and the help of Dr. C. L. Qin. Furthermore, we would like to thank the support of Research and Development Project on Advanced Metallic Glasses Inorganic Materials and Joining Technology, Institute for Materials Research, Tohoku University.

\section{REFERENCES}

1) T. Zhang, A. Inoue and T. Masumoto: Mater. Sci. Eng. A 181 (1994) 1423-1426.

2) A. Inoue: Mater. Trans., JIM 36 (1995) 866-875.

3) A. Inoue: Mater. Sci. Eng. A 226-228 (1997) 357-363.

4) A. Inoue, N. Nishiyama, K. Amiya, T. Zhang and T. Masumoto: Mater. Lett. 19 (1994) 131-135.

5) K. Amiya, N. Nishiyama, A. Inoue and T. Masumoto: Mater. Sci. Eng. A 179-180 (1994) 692-696.

6) T. Zhang and A. Inoue: Mater. Trans., JIM 39 (1998) 1001-1006.

7) T. Zhang and A. Inoue: Mater. Sci. Eng. A 304-306 (2001) 771-774.

8) Y. C. Kim, W. T. Kim and D. H. Kim: Mater. Sci. Eng. A 375-377 (2004) 127-135.

9) J. M. Park, Y. C. Kim, W. T. Kim and D. H. Kim: Mater. Trans. 45 (2004) 595-598.

10) C. L. Ma, H. Soejima, S. Ishihara, K. Amiya, N. Nishiyama and A. Inoue: Mater. Trans. 45 (2004) 1802-1806.

11) K. Asami, C. L. Qin, T. Zhang and A. Inoue: Mater. Sci. Eng. A 375377 (2004) 235-239.

12) C. L. Qin, W. Zhang, K. Asami, N. Ohtsu and A. Inoue: Acta Mater. 53 (2005) 3903-3911.

13) A. Takeuchi and A. Inoue: Mater. Trans. 46 (2005) 2817-2829.

14) T. Egami and Y. Waseda: J. Non-Cryst. Solids 64 (1984) 113-116.

15) S. Hiromoto, A. P. Tsai, M. Sumita and T. Hanawa: Corros. Sci. 42 (2000) 2193-2200.

16) A. Kawashima, T. Sato, N. Ohtsu and K. Asami: Mater. Trans. 45 (2004) 131-136.

17) X. Y. Li, E. Akiyama, H. Habazaki, A. Kawashima, K. Asami and K. Hashimoto: Corros. Sci. 41 (1999) 1095-1118.

18) M. Pelanvin, D. N. Hendrickson, J. M. Hollander and W. L. Jolly: J. Phys. Chem. 74 (1970) 1116-1121. 